\title{
OCCURRENCE AND DIVERSITY OF ARBUSCULAR MYCORRHIZAL FUNGI IN TRAP CULTURES FROM SOILS UNDER DIFFERENT LAND USE SYSTEMS IN THE AMAZON, BRAZIL
}

\author{
Patrícia Lopes Leal'; Sidney Luiz Stürmer ${ }^{2 *}$; José Oswaldo Siqueira ${ }^{3}$ \\ ${ }^{1}$ Departamento de Microbiologia, Universidade Federal de Viçosa, Viçosa, MG, Brasil; ${ }^{2}$ Universidade Regional de Blumenau, \\ Departamento de Ciências Naturais, Blumenau, SC, Brasil; ${ }^{3}$ Universidade Federal de Lavras, Departamento de Ciência de Solo, \\ Lavras, MG, Brasil
}

Submitted: March 18, 2008; Returned to authors for corrections: October 29, 2008; Approved: February 25, 2009.

\begin{abstract}
The aim of this work was to evaluate the occurrence of arbuscular mycorrhizal fungi (AMF) species diversity in soil samples from the Amazon region under distinct land use systems (Forest, Old Secondary Forest, Young Secondary Forest, Agroforestry systems, Crops and Pasture) using two distinct trap cultures. Traps established using Sorghum sudanense and Vigna unguiculata (at Universidade Regional de Blumenau FURB) and Brachiaria decumbens and Neonotonia wightii (at Universidade Federal de Lavras - UFLA) were grown for 150 days in greenhouse conditions, when spore density and species identification were evaluated. A great variation on species richness was detected in several samples, regardless of the land use systems from where samples were obtained. A total number of $24 \mathrm{AMF}$ species were recovered using both methods of trap cultures, with FURB's traps yielding higher number of species. Acaulospora delicata, A. foveata, Entrophospora colombiana and two undescribed Glomus species were the most abundant and frequent species recovered from the traps. Number of species decreased in each genus according to this order: Acaulospora, Glomus, Entrophospora, Gigaspora, Archaeospora, Scutellospora and Paraglomus. Spore numbers were higher in Young Secondary Forest and Pastures. Our study demonstrated that AMF have a widespread occurrence in all land use systems in Amazon and they sporulate more abundantly in trap cultures from land uses under interference than in the pristine Forest ecosystem.
\end{abstract}

Key-words: Amazon Forest, soil fungi, species diversity, pot cultures, pastures, agroforestry systems.

\section{INTRODUCTION}

Arbuscular mycorrhizal fungi (AMF) are one of the most and widespread important components of the soil biota in natural and agriculture systems. They are obligate symbionts currently placed within the Division Glomeromycota (27) that establish endomycorrhizal associations with up to $90 \%$ of plant families (32). AMF are particularly important in tropical regions where soils usually present low fertility and mycorrhizal is thought to play a crucial role for growth, survival and development of plant species and thus influencing plant secondary succession and community structure (9). Their benefits may involve better access to soil resources and enhancement of soil aggregation and stability (26) and protection against phytopathogens (22). In addition to their individual plant effects, at plant community level AMF can be mediators of competition influencing plant biodiversity (40) and sustainability of terrestrial ecosystems. AMF ubiquous presence and their taxonomic, genetic and functional diversity are directly related to plant and soil processes $(2,23)$ and therefore there is an increasing interest in the assessment of the biodiversity and functions of AMF communities (14). Although biodiversity has been a major research topic in terrestrial ecology, it has been largely ignored in terms of soil biota mainly in the tropical regions (18).

*Corresponding Author. Mailing address: Universidade Regional de Blumenau (FURB), Departamento de Ciências Naturais (DCN), Cx.P. 1507. 8912-900 Blumenau, SC, Brasil. Fone: 5547 3321-0470; Fax: 5547 3321-0233. e-mail: sturmer@furb.br 
Diversity of AMF species is measured mainly by extracting, counting and identifying their field collected asexual spores, the fungal propagule that possess morphological characters to define species in this group of organisms (21) although molecular techniques have been revealed an useful tool for characterization and identification of AMF (12). Species richness and abundance of AMF in a given ecosystem are influenced by large scale historical factors like long-distance dispersion and vicariance (25) and local ecological factors such as plant cover and host diversity, soil cultivation and disturbance and seasonality (32), being all of these factors important in the study of AMF diversity (21). Field-collected spores, however, are found in some circumstances in low numbers, parasitized, lacking informative taxonomic characteristics impairing a more accurate identification as components of spore walls are susceptible to alteration and deterioration by a wide sort of agents in the soil. Establishment of trap cultures using bulk soil or by mixing rhizosphere soil and root pieces with sterilized diluents and growing with suitable hosts, represents a strategy to yield a large number of healthy spores which can be readily identifiable and supplement the assessment of local species diversity in different ecosystems. This methodology not necessarily allows the identification of all species, because sporulation of the fungal community may be affected by the plant host chosen for trapping (2) whereas in some cases it can promotes the sporulation of cryptic AMF species that were not sporulating at the sampling time or field conditions (37).

Despite of that, trap cultures have been widely used to access AMF diversity and isolate indigenous fungi (21). Miller et al. (17) recovered 14 AMF species in Sorghum and Coleus trap cultures that were not previously present in field sampling of apple orchards. Bever et al. (2) established Sorghum trap cultures and also transplanted intact plants from the field to microcosms in order to complement their diversity estimates based on field collected spores from mown grassland. They observed that transplanted traps yielded the lowest diversity and total spore numbers and that no single sampling procedure was able to recover all fungal species found in this study. In Brazil, despite the relatively large number of surveys of AMF in different ecosystems (38), the use of trap cultures in biodiversity studies is still limited. Klauberg Filho et al. (11), working in heavy metal polluted site, detected 21 AMF species from which 12 were detected only in trap cultures with Brachiaria decumbens. In bauxite mining soils, Melloni et al. (16) used Brachiaria ruziziensis and Neonotonia wightii to recover AMF species from field soils and Souza et al. (33), in the arid region of Northeast Brazil, baited 24 AMF species using Panicum miliaceum as the host plant. Moreover, abundant sporulation produced by distinct AMF species is critical to set up single species cultures and further characterization of fungal isolates as experimental units (36).

The Brazilian ecosystems are characterized as important sources of AMF diversity. According to Stürmer and Siqueira
(38), inventories resulted from 28 surveys carried out in only $35 \%$ of the politically defined states revealed the occurrence of 79 AMF species in the Brazilian territory. Studies were mainly concentrated in the Southeast region where quantitative and qualitative community, ecological and functional assessment have been carried out (30). Some regions of the country have been virtually unsampled for AMF studies including the Middle West and the North regions where extensive wide and important ecosystems like the large flooded Pantanal and the Amazon Forest are located. A multidisciplinary research project has been launched in the western Amazon to evaluate the below ground diversity of several soil organisms. AMF species diversity was evaluated as part of this project trough morphological identification of field collected spores and trap cultures spores. In this work, we report data of AMF diversity obtained in soils from pristine Amazon forest and distinct land use systems using trap cultures techniques.

\section{MATERIALS AND METHODS}

\section{Study Sites}

The study sites are located in Benjamin Constant municipality $\left(4^{\circ} 21^{\prime}\right.$ and $4^{\circ} 26^{\prime} \mathrm{S}, 69^{\circ} 36^{\prime}$ and $\left.70^{\circ} 1^{\prime} \mathrm{W}\right)$, in the Alto Solimões river region, western part of the Amazon state, in the border with Peru and Colombia. The climate of the area is tropical humid and super humid (Af according to Köppen) with average annual temperature of $25.7^{\circ} \mathrm{C}$ and rainfall of 2,562 $\mathrm{mm}$. Land use systems (LUS) sampled included pristine Amazon Forest (F, n $=17)$, Old ( $>20$ years old) Secondary Forest (OSF, $n=10)$, Young Secondary Forest (YSF, $\mathrm{n}=30$ ), Agroforestry systems $(A F, n=10)$, Crop $(C, n=18)$ and Pasture land $(P, n=13)$ located in the neighborhoods of Benjamin Constant town and in the rural communities of Nova Aliança and Guanabara II. Soil pH was 4.0 to 6.4 , soil phosphorus was 1.4 to $10 \mathrm{mg} \mathrm{dm}^{-3}$ and organic matter ranged from 1.0-2.6\%. Forest sites are covered by pristine Amazon forest and secondary forest sites are covered by secondary vegetation in distinct successional stages; this LUS was further divided in old secondary forest ( $>$ 20 years old) or young secondary forest $(<20$ years old). Agroforestry sites were formed predominantly by the spontaneous regeneration of secondary forest species with introduction of cultivated species like cupuaçu (Theobroma grandiflorum), pupunha (Bactris gassipaes), mapati (Pourouma cecropiifolia), ingá (Inga sp.), abiu (Pouteria sp.), açaí (Euterpe precatoria), pineapples and banana. Crop sites are cultivated with cassava (Manhiot esculenta), maize and banana. Plant cover in pasture site was dominated by capim imperial (Axonopus scoparius), brachiaria (Brachiaria brizantha, B. humidicola) and grama batatais (Paspalum notatum), among several invasive species. Further information for characterization of the land use, cover and soil type of the area studied is reported in Fidalgo et al. (5). 


\section{Sampling Design and soil collection}

Six grids of 16 regularly spaced points (100 m mesh size) spanning all LUS were established at the study sites. A wood stick was placed in each sampling point to refer the center point as a reference by all teams participating of the research program Conservation and Sustainable Management of Below Ground Biodiversity (Research Group BiosBrasil) which involved soil chemical and physical characterization, soil fungi, nematodes, nitrogen fixing bacteria, soil fauna, termites, carabids, ants, fruit flies and plant community. A total of 98 sampling points were sampled: 80 of them corresponding to the main center point and 18 of them allocated in between two main center points and distant $50 \mathrm{~m}$ from those. Four (4) soil subsamples were collected $3 \mathrm{~m}$ from the center point oriented in the cardinal directions. Another 8 subsamples were collected $6 \mathrm{~m}$ from the center point: 4 oriented in the cardinal directions and 4 between them. These 12 subsamples were collected with a soil core sampler at $0-20 \mathrm{~cm}$ depth and pooled in a plastic bag. The soil core sampler was flamed sterilized in the field between each sampling. Soil samples were further homogenized in plastic trays, placed back into new plastic bags which were accommodated within boxes and sent by air mail to Universidade Federal de Lavras (UFLA) and Universidade Regional de Blumenau (FURB) for establishing trap cultures and used for soil physical and chemical analysis.

\section{Trap cultures}

Because of the difficult and high cost of sampling, we decided to set up different trap cultures at the Universidade Regional de Blumenau (FURB), in Blumenau, Santa Catarina state, and at the Universidade Federal de Lavras (UFLA), in Lavras, Minas Gerais state, in order to guarantee and maximize sporulation of indigenous AMF, mainly the criptic species. Traps were established and let to grow for up to five months under greenhouse conditions. At FURB, soil samples containing root pieces were thoroughly homogenized $(1: 1, \mathrm{vol}: \mathrm{vol})$ with sand sterilized twice by autoclave $\left(121^{\circ} \mathrm{C}, 1\right.$ hour with intervals of 24 $\mathrm{h}$ between autoclaving) and accommodated in $1.5 \mathrm{Kg}$ plastic pots $(15 \mathrm{~cm}$ wide and $13 \mathrm{~cm}$ high). Before sowing, seeds of Sorghum sudanense and Vigna unguiculata were surface disinfected by immersing them in a $0.5 \%$ sodium hypochlorite solution for $15 \mathrm{~min}$. After washing the seed with distilled water, they were sown at $2 \mathrm{~cm}$ depth in each pot and covered with sterilized sand. Approximately 50-60 seeds of Sorghum and 4-6 seeds of Vigna were sown per pot and all germinated seedlings were kept in the pot. Pots were irrigated daily as needed and no fertilization was added during the growth period. At UFLA, traps were established by placing $200 \mathrm{~g}$ of soil samples with root pieces as layers sandwiched between two layers of sterilized soil $\left(121^{\circ} \mathrm{C}, 1\right.$ hour with intervals of $24 \mathrm{~h}$ between autoclaving). Plastic pots used were $10 \mathrm{~cm}$ wide and $20 \mathrm{~cm}$ height having the capacity to accommodate $1.5 \mathrm{Kg}$ of soil. Pots were first filled with sterile sand up to $12 \mathrm{~cm}$, the soil inoculum was added and topped with another $3 \mathrm{~cm}$ layer of sterile sand, and seeds were then added and covered with sterile sand. Seeds of Neonotonia wightii and Brachiaria decumbens were surface disinfected with $0.5 \%$ sodium hypochlorite for $15 \mathrm{~min}$ and their dormancy interrupted by immersing them in concentrated sulfuric acid. In each pot, 5-10 seeds of Brachiaria and 10-20 seeds of Neonotonia were added and trimmed to 3 plants per pot after seedling emergence. Once a month, pots were watered as needed and fertilized with $20 \mathrm{ml}$ per pot of Hogland's solution.

At the end of the five months growing cycle, $50 \mathrm{~g}$ soil was sampled from each pot for AMF spore extraction, counting and identification. Spores were extracted by the wet sieving method (7) followed by sucrose gradient centrifugation ( $20 \%$ and $60 \%$ ). Under the dissecting microscope, spores were separated by morphotypes and counted. For identification, spores were mounted on slides in PVLG and PVLG + Melzer's reagent as the mounting media. AMF species were identified based on subcellular structures of asexual spores following description of living reference cultures (http://invam.caf.wvu.edu) and species description protocols. Relative abundance of the AMF species most prolific sporulators within a LUS was calculated as its contribution to the total sporulation and frequency of occurrence was calculated as the number of traps that an AMF species sporulated relative to the total number of traps established, both expresses in percentage. A trap culture was considered positive when new and fresh spores were detected at the end of the growing cycle. AMF species were ranked into Generalists (G) if they sporulated in 5 or 6 LUS, Intermediate (I) if they sporulated in 2 to 4 LUS and Exclusive (E) if sporulation was detected in only one LUS.

\section{Statistical Analysis}

Spore counting were submitted to the analysis of Generalized Mixed Linear Models considering LUS at the random variable and applying Duncan's test $(\mathrm{P}<0.05)$. The statistical package utilized for all other analysis was NTSYS (Numerical Taxonomic and Multivariate Analysis System) and Hammer et al. (8).

\section{RESULTS}

\section{Spore abundance}

A total of 184 trap cultures (92 at UFLA and 92 at FURB) were established with field soils originating from different Amazonian land use systems. Soils from some sampling points were not used to set up trap cultures due to the amount of soil collected in the field explaining the discrepancy between the total number of field soil samples and trap cultures established. Sporulation was quite frequent and abundant for most traps, except those from Forest which only $28 \%$ yielded new AMF spores (Table 1). New spore production was positive in $72 \%$ of those traps from Old Secondary Forest to over $90 \%$ in samples 
Table 1. Number of total and positive trap cultures and spore numbers of AMF per Land Use System.

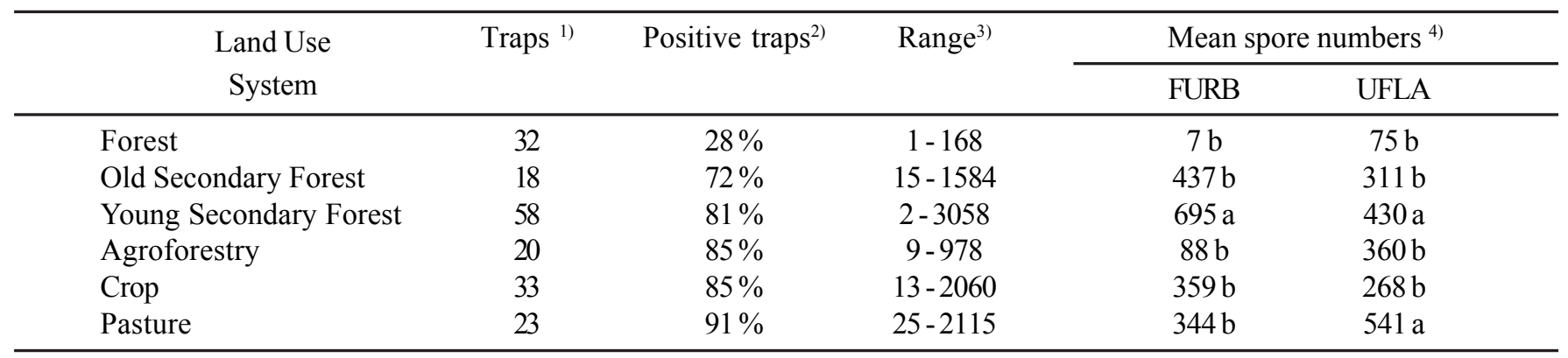

1) Traps = values represent the total number of traps established per LUS considering both localities (UFLA and FURB);

2) Percentage of trap cultures that yielded newly formed AMF spores;

3) Numbers represent the smallest - the highest number of spore recovered in a trap culture within each LUS;

4) Mean number of AMF spores $/ 50 \mathrm{ml}$ soil. Means followed by the same letter within the column are not statistically different (Duncan's test, $\mathrm{P}<0.05)$.

from Pasture. Due to this variation on the sporulation of traps according to each LUS, further analysis on AMF spore numbers and frequency of occurrence will be carried out considering only those traps with positive sporulation. Overall, the lowest AMF spore abundance was recovered in traps from Forest sites (1-168 spores/50 ml soil) and Agroforestry sites (9-978 spores/ $50 \mathrm{ml}$ soil) (Table 1). Traps established from Young Secondary Forest, Pasture and Crops samples tended to produce large number of spores (Table 1). At UFLA, the highest total number of spores was detected in Pasture and Young Secondary Forest (541 and 430 spores/50 $\mathrm{ml}$ soil, respectively) while at FURB, the largest number of spores was found in Young Secondary Forest (695 spores/50 ml soil) followed by Old Secondary Forest (437 spores/50 ml soil) (Table 1).

\section{Species Diversity}

A total of 23 AMF species were recovered after one growth cycle of all traps (Table 2) indicating that our trapping systems were quite successful for most LUS. All genera and families of Glomerales were detected in trap cultures established from samples, except Pacispora belonging to Family Pacisporaceae. Forest and Old Secondary Forest traps yielded three genera each while 4 or 5 genera were detected in the remaining LUS. Most of sporulating species belong to the genera Acaulospora (10 species) followed by Glomus (5 species) which were represented in all LUS (Tables 3 and 4). The genera Scutellospora and Paraglomus were represented by only one species while two species were recovered for Entrophospora, Gigaspora and Archaeospora each. From the total number of species recovered, six could not be attributed to described species and three of them will be briefly described as they are similar to known species. Spores of Glomus "thin green" are 90-130 $\mu$ m diameter, spore wall composed of two layers: L1 $1 \mu \mathrm{m}$ thick and L2 ranging from $2-5 \mu \mathrm{m}($ mean $=3.4)$, resembling Glomus eburneum
Kennedy, Stutz and Morton. Glomus "yellow" resembles Glomus versiforme (Karsten) Berch and has the spore wall composed by two layers: L1 $1 \mu \mathrm{m}$ thick and L2 ranging from 6$9 \mu \mathrm{m}$ (mean = 7.1). Spores of Acaulospora "honey comb" are 90-100 $\mu \mathrm{m}$ diameter, spore wall is ornamented with circular reticulum with a smooth center and two bilayered germinal walls (gw) are present, the innermost layer of gw2 turning light pink to reddish in Melzer's reagent. Acaulospora "honey comb" resembles Acaulospora bireticulata Rothwell and Trappe and is putatively a new species, differing mainly by the pattern of ornamentation of the spore wall (smooth circular reticulum compared to polygonal reticulum with projections at the center of polygons as in $A$. bireticulata).

A total of 10 and $20 \mathrm{AMF}$ species were detected sporulating in traps established at UFLA and FURB, respectively (Table 3). Acaulospora delicata, A. morrowiae, Entrophospora colombiana, Glomus clarum, Glomus "thin green", Gigaspora sp. and Archaeospora leptoticha were the only species detected at both UFLA and FURB. The highest number of species was recovered from traps established with Young Secondary Forest and Crops samples, with 14 and 13 species sporulating, respectively, while only five species were detected for Forest traps (Table 3). Glomus "thin green" and A. delicata sporulated in trap cultures from all LUS and represented the most frequent species recovered, with $39.2 \%$ and $21.5 \%$ frequency of occurrence, respectively (Table 3). Acaulospora foveata, Entrophospora colombiana and Glomus "yellow" were also widespread sporulators being detected in traps from all LUS except those from Forest sites, followed by Acaulospora morrowiae which was not detected only in Forest and Pasture samples. The remaining 17 AMF species were detected in less than $5 \%$ of the positive trap cultures being detected in traps from only one or two LUS (Table 3). The most prolific sporulator in trap cultures was Glomus "thin green" and Acaulospora 
Table 2. Genera and species of arbuscular mycorrhizal fungi (AMF) in each Land Use System recovered after trap cultures at FURB and UFLA.

\begin{tabular}{|c|c|c|}
\hline Land Use System & Genera & AMF Species \\
\hline \multirow[t]{3}{*}{ Forest } & Acaulospora & $\begin{array}{l}\text { A. delicata Walker, Pfeiffer \& Bloss } \\
\text { A. mellea Spain \& Schenck }\end{array}$ \\
\hline & Glomus & Glomus "thin green" \\
\hline & Gigaspora & $\begin{array}{l}\text { Gigaspora margarita Becker \& Hall } \\
\text { Gigaspora } \text { sp. }\end{array}$ \\
\hline \multirow[t]{3}{*}{ Old Secondary Forest } & Acaulospora & $\begin{array}{l}\text { A. delicata Walker, Pfeiffer \& Bloss } \\
\text { A. foveata Trappe \& Janos } \\
\text { A. morrowiae Spain \& Schenck }\end{array}$ \\
\hline & Entrophospora & E. colombiana Spain \& Schenck \\
\hline & Glomus & $\begin{array}{l}\text { Glomus "thin green" } \\
\text { Glomus "yellow" } \\
\text { Glomus "brown" }\end{array}$ \\
\hline \multirow[t]{4}{*}{ Young Secondary Forest } & Acaulospora & $\begin{array}{l}\text { A. delicata Walker, Pfeiffer \& Bloss } \\
\text { A. foveata Trappe \& Janos } \\
\text { A. morrowiae Spain \& Schenck } \\
\text { A. scrobiculata Trappe } \\
\text { A. rehmii Sieverding \& Toro } \\
\text { A. "honey comb" }\end{array}$ \\
\hline & Entrophospora & $\begin{array}{l}\text { E. colombiana Spain \& Schenck } \\
\text { E. infrequens (Hall) Ames \& Schneider }\end{array}$ \\
\hline & Glomus & $\begin{array}{l}\text { Glomus "thin green" } \\
\text { Glomus "yellow" } \\
\text { Glomus clarum Nicol. \& Schenck } \\
\text { Glomus claroideum Schenck \& Smith }\end{array}$ \\
\hline & $\begin{array}{l}\text { Gigaspora } \\
\text { Archaeospora }\end{array}$ & $\begin{array}{l}\text { Gigaspora } \mathrm{sp} . \\
\text { Ar. trappei (Ames \& Linderman) Morton \& Redecker }\end{array}$ \\
\hline \multirow[t]{3}{*}{ Agroforestry } & Acaulospora & $\begin{array}{l}\text { A. delicata Walker, Pfeiffer \& Bloss } \\
\text { A. foveata Trappe \& Janos } \\
\text { A. morrowiae Spain \& Schenck }\end{array}$ \\
\hline & $\begin{array}{l}\text { Entrophospora } \\
\text { Glomus }\end{array}$ & $\begin{array}{l}\text { E. colombiana Spain \& Schenck } \\
\text { Glomus "thin green" } \\
\text { Glomus "yellow" }\end{array}$ \\
\hline & Paraglomus & P. occultum (Walker) Morton \& Redecker \\
\hline \multirow[t]{4}{*}{ Crop } & Acaulospora & $\begin{array}{l}\text { A. delicata Walker, Pfeiffer \& Bloss } \\
\text { A. foveata Trappe \& Janos } \\
\text { A. morrowiae Spain \& Schenck } \\
\text { A. scrobiculata Trappe } \\
\text { A. spinosa Walker \& Trappe } \\
\text { A. "honey comb" }\end{array}$ \\
\hline & Entrophospora & $\begin{array}{l}\text { E. colombiana Spain \& Schenck } \\
\text { E. infrequens (Hall) Ames \& Schneider }\end{array}$ \\
\hline & Glomus & $\begin{array}{l}\text { Glomus "thin green" } \\
\text { Glomus "yellow" } \\
\text { Glomus clarum Nicol. \& Schenck }\end{array}$ \\
\hline & $\begin{array}{l}\text { Scutellospora } \\
\text { Archaeospora }\end{array}$ & $\begin{array}{l}\text { Scutellospora } \text { sp. } \\
\text { Ar. leptoticha (Schenck \& Smith) Morton \& Redecker }\end{array}$ \\
\hline
\end{tabular}


Leal, P.L. et al.

Pasture

Entrophospora

Glomus

Gigaspora

Archaeospora
A. delicata Walker, Pfeiffer \& Bloss

A. foveata Trappe \& Janos

A. tuberculata Janos \& Trappe

A. bireticulata Rothwell \& Trappe

E. colombiana Spain \& Schenck

E. infrequens (Hall) Ames \& Schneider

Glomus "thin green"

Glomus "yellow"

Gigaspora sp.

Ar. leptoticha (Schenck \& Smith) Morton \& Redecker

Table 3. Frequency of occurrence (\%), Locality and Range of habitat of AMF species recovered from trap cultures in different Land Use Systems. Range of habitat (R) refers whether a species is Generalist (G), Intermediate (I) or Exclusive (E) across LUS.

\begin{tabular}{|c|c|c|c|c|}
\hline AMF Species & Locality & LUS & Range & $\begin{array}{c}\text { Frequency } \\
(\%)\end{array}$ \\
\hline A. delicata Walker, Pfeiffer \& Bloss & UFLA, FURB & F, OSF, YSF, AF, C, P & G & 21.5 \\
\hline A. foveata Trappe \& Janos & FURB & OSF, YSF, AF, C, P & G & 13.3 \\
\hline A. morrowiae Spain \& Schenck & UFLA, FURB & OSF, YSF, AF, C & I & 6.0 \\
\hline A. scrobiculata Trappe & UFLA & YSF, C & I & 1.5 \\
\hline A. mellea Spain \& Schenck & FURB & $\mathrm{F}$ & $\mathrm{E}$ & $<1$ \\
\hline A. rehmii Sieverding \& Toro & FURB & YSF & $\mathrm{E}$ & $<1$ \\
\hline A. spinosa Walker \& Trappe & FURB & $\mathrm{C}$ & $\mathrm{E}$ & $<1$ \\
\hline A. tuberculata Janos \& Trappe & FURB & $\mathrm{P}$ & $\mathrm{E}$ & $<1$ \\
\hline A. bireticulata Rothwell \& Trappe & FURB & $\mathrm{P}$ & $\mathrm{E}$ & $<1$ \\
\hline A. "honey comb" & FURB & YSF, C & I & 4.4 \\
\hline E. colombiana Spain \& Schenck & UFLA, FURB & OSF, YSF, AF, C, P & G & 7.4 \\
\hline E. infrequens (Hall) Ames \& Schneider & FURB & YSF, C,P & I & 2.2 \\
\hline Glomus "thin green" & UFLA, FURB & F, OSF, YSF, AF, C, P & G & 39.2 \\
\hline Glomus "yellow" & UFLA & OSF, YSF, AF, C, P & G & 8.1 \\
\hline Glomus "brown" & FURB & OSF & $\mathrm{E}$ & $<\mathbf{1}$ \\
\hline Glomus clarum Nicol. \& Schenck & UFLA, FURB & YSF, C & I & 1.5 \\
\hline Glomus claroideum Schenck \& Smith & FURB & YSF & E & $<1$ \\
\hline Gigaspora margarita Becker \& Hall & FURB & $\mathrm{F}$ & $\mathrm{E}$ & $<1$ \\
\hline Gigaspora sp. & UFLA, FURB & F, YSF, P & I & 2.2 \\
\hline Scutellospora sp. & FURB & $\mathrm{C}$ & $\mathrm{E}$ & $<1$ \\
\hline Ar. trappei (Ames \& Linderman) Morton \& Redecker & UFLA & YSF & $\mathrm{E}$ & $<1$ \\
\hline Ar. leptoticha $($ Schenck \& Smith) Morton \& Redecker & UFLA, FURB & $\mathrm{C}, \mathrm{P}$ & I & 2.9 \\
\hline P. occultum (Walker) Morton \& Redecker & FURB & $\mathrm{AF}$ & $\mathrm{E}$ & $<1$ \\
\hline
\end{tabular}

foveata followed by Acaulospora delicata and Entrophospora colombiana (data not shown). These species also represent generalist $(\mathrm{G})$ species occurring in at least five of the six LUS analyzed. Most of the remaining species sporulated weakly in traps and corresponded to intermediate (I) or exclusive (E) species. Some species like A. scrobiculata, A. tuberculata, Glomus clarum and Glomus claroideum, despite their low frequency of occurrence (sporulated in $<1 \%$ of the samples) produced spores ranging from 115 - 140 per $50 \mathrm{ml}$ soil (data not shown).

For those species occurring in at least four LUS, the magnitude of their sporulation was influenced by the LUS (Fig. 1). Organisms of all species, except $A$. morrowiae, sporulated more abundantly in pots established with field soils from Young Secondary Forest. Glomus "thin green" was the less selective species, sporulating prolifically in most of LUS, except Forest, 


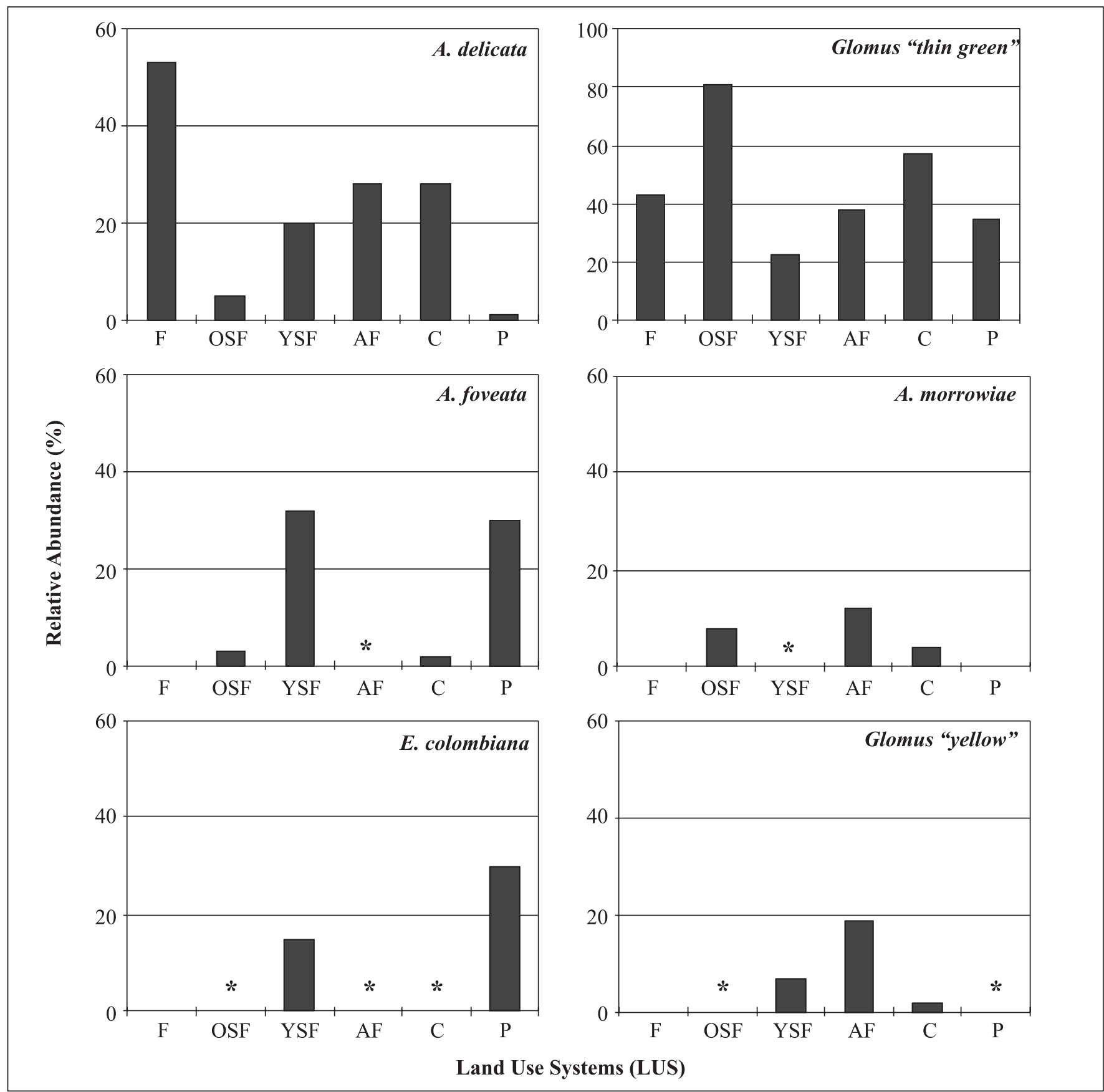

Figure 1. Relative abundance (\%) of the most prolific sporulators according to each land use system (LUS). Asterisks indicate LUS where relative abundance was $<1 \%$.

while $A$. foveata, A. morrowiae and E. colombiana were more specific - Acaulospora foveata and Entrophospora colombiana sporulated prolifically in traps from Young Secondary Forest and Pasture, and Acaulospora morrowiae sporulated prolifically in traps from Agroforestry and Crop traps (Fig. 1).

\section{DISCUSSION}

In this study, we reported for the first time the occurrence of AMF species associated with pristine forest and distinct land use systems located at the Upper Solimões River, at the heart of 
the Amazon forest. Although this study recovered 23 AMF species sporulating in trap cultures, we acknowledge that this number does not represent the total alpha diversity of AMF occurring in these ecosystems as undergoing analysis from field collected spores has revealed so far $c a$. 60 different morphotypes (Stürmer and Siqueira, unpublished data). Nevertheless, AMF species richness in our study is higher than that reported by Lovelock and Ewel (14) or of equal magnitude as reported by Picone (24) and Mangan et al. (15) from field soils of tropical forests. This evidence that trap cultures might act as a filter allowing sporulation of only part of the indigenous AMF species which are aggressive enough to colonize and sporulate in a fast growing host under artificial conditions and short time span. Nevertheless, this approach should be incorporated in the analysis of AMF species diversity as it revealed non-sporulating AMF species in apple orchards (17), mown grasslands (2) and arid ecosystems (39) and produce healthy spores which can be used to establish single species cultures. In our study, the efficiency of trap cultures on yielding AMF spores was highly variable according to each LUS and those established from Forest sites were the most unsuccessful. We are not able to provide a complete explanation for this particular result from the Forest sites. It has been found that the mycorrhizal inoculum potential of soils from this area are very low and relatively equal amongst LUS ( 0 - 3.56 propagules $\mathrm{g}^{-1}$ soil) according to a MPN bioassay using Allium sp. as the host plant (28). Another possibility is that AMF species from Forest sites are preferentially living in decomposing leaves in the forest litter (not included in our traps), as demonstrated by Aristizábal et al. (1). We can hypothesize that the mycorrhizal community occurring at Forest sites are composed of more fastidious species that would take a longer time to colonize the root cortex and to reach a threshold level of colonization before sporulating (6). Therefore, we can also invoke that AMF species has distinct $r$ and $k$ strategies $(34,36)$. High sporulation in trap culture might reflect an $r$ strategy of some species that allocate most of the carbon to sporulation while a $k$ strategy might be represented by those species that are not prolific sporulators and allocate resource to vegetative growth. In this work, trap cultures underwent only one growth cycle of five months, which could not have been enough for some fungal strains to sporulate. Considering their long term in the same hosts and stable environmental conditions in nature, preferential host and environmental fitness may have developed, thereby affecting their sporulation in trapping systems.

Trap cultures established at FURB yielded a higher number of species than those established at UFLA. Although our objective was not to compare both methodologies of trapping, thoroughly homogenizing the soil with the sterile diluent increases the chances of fungal propagules of all species to encounter susceptible root cells and establish symbiosis. Nevertheless, concentrating the inoculum source may provide an efficient method to screen the ability of plant seedlings to establish mycorrhizal association (3) and might favor more aggressive species to colonize the trap hosts. Bever et al. (2) were able to detect 18 out of 23 AMF species occurring in a 75 $\mathrm{m}^{2}$ area of mown grassland using Sorghum trap cultures with homogenized inoculum compared with only 10 species recovered in traps established by transplanting hosts from the field. This suggests that not all species native to that field were colonizing spontaneous field plants. An alternative explanation for differences on the efficiency of traps in recovering AMF species could be related with the abundance of host plants grown in each pot. Pots were heavily seeded with Sorghum at FURB while at UFLA traps only three seedlings were grown in trap cultures pots. This procedure will influence directly on the amount of roots produced within each pot available for establishment of root colonization and consequently sporulation by different fungal species. Efficiency of Sorghum as a host plant for trapping AMF species has been well established $(4,20)$ with soils from different geographical locations. Our results indicate that the homogenization of field soil inoculum allied with a $\mathrm{C} 4$ heavily seeded grass seems to be an appropriate approach to induce freshly produced spores of AMF species occurring in a large variety of tropical soils. Despite that, we should not rule out the use of two different trapping methodologies to characterize AMF species diversity as some fungal species were detected only at UFLA and others only at FURB, turning both trap methods complementary.

Total number of spores produced by AMF was significantly higher at Young Secondary Forest and Pasture trap cultures compared to other LUS independent of the trapping utilized and the lowest number of spores was registered in traps from Forest. Sporulation in trap cultures depends also of the original mycorrhizal inoculum potential of the soil, although this factor might be ruled out since all soils had a very low MPN values (28). Other factors impacting spore germination like moisture availability or even predation and hyperparasitism of spore (29) might result in loss of spore viability turning this propagule unavailable to start mycorrhiza in the traps hosts. Nevertheless, natural ecosystems, represented by Forest sites in this study, might be more stable than other LUS regarding the presence of host plants and absence of variation in soil characteristics that could act as selection pressure on fungal assemblages with reduced sporulation or that produce spores with low capacity to resist adverse conditions but with adaptation for a predominant vegetative life stage (29), imparing their detection in only one growth cycle of trapping. This is consistent with findings of low spore density in climax forests (41), low compatibility and mycorrhizal responsiveness of host tropical climax tree species (31) and AMF colonization of decomposing leaves (1). The high density of spores found in Young Secondary Forest and Pasture may result from shift in plant community and reduced nutrient availability in the soil, as a consequence of organic matter oxidation and increased nutrient uptake by 
the growing vegetation. Fast growing tree species that dominate the Young Secondary Forest and Brachiaria decumbens, the grass species that dominates the Pasture, are highly mycotrophic species (31) that could have contributed for higher propagule production in both LUS.

The composition of AMF communities and spore abundance are affected by the host plant through their effects upon propagule activation, hyphal development and sporulation $(2,29)$. The total spore number produced by each AMF species in trap cultures was highly variable according to each LUS. For instance, Glomus "thin green" sporulated poorly in pots from Young Secondary Forest and Crop compared to Forest while $A$. foveata and E. colombiana sporulated prolifically in traps from Young Secondary Forest and Pasture compared to other LUS. Differential sporulation rates of AMF species have been observed according to the trap cultures methods and the trap hosts. Bever et al. (2) found that A. mellea sporulated only in Sorghum cultures but not in transplant cultures while Gigaspora gigantea and Scutellospora calospora produced larger amounts of spores in the former method than in the latter and speculated about the host-dependent sporulation of AMF species. Liu and Wang (13) observed that species of Glomus sporulated preferentially when Zea mays was the host plant while sporulation of Acaulospora species was higher with Potentilla anserina than with other three hosts. The pattern observed in our study seems not to be host trap dependent because we used four distinct hosts to detect AMF species but rather we speculate that it represents intraspecific and interpopulational variation exhibited by indigenous Amazonian AMF in their ability to sporulate in our trapping systems. The intraspecific component of this variability is observed when the same AMF species sporulated at different rates within the same LUS (data not shown) while the interpopulational component is detected by comparing sporulation rates of the same AMF species in distinct LUS (Fig. 1). Detection of this variability is important to understand the biology of these fungi in terrestrial systems and address questions whether changes in the ecosystem components (in this study represented by LUS) impacts the fitness (measured by sporulation) of the indigenous AMF. Moreover, detecting isolates with different sporulation rates represents a first step for screening the genetic diversity exhibited by AMF species/strains over distinct geographic locations which may impact plant benefits these fungi confer to their hosts (35) and allows further detection of genetic variation using molecular tools (12).

This study indicates that distinct land use systems in the Amazon region harbors a diverse community of AMF species as measured by the methodology of trap cultures and revealed some putatively new species. Detection of this diversity is enhanced by distinct methodologies of trapping, with distinct host species and host densities, distinct inoculum distribution within trap pots and culturing in different geographical locations as carried out in our study. AMF species richness detected on trap cultures was variable among LUS and young secondary forest and crops yielded the highest species richness. Detection of differences on mycorrhizal community among LUS in the Amazon is important to characterize the biological variability occurring in this biome and provide an important initial step for characterization and conservation of germplasm of this important group of soil organisms.

\section{ACKNOWLEDGEMENTS}

This work was part of the requirements of the senior author for a Master of Science degree in Agricultural Microbiology at the Universidade Federal de Lavras (UFLA). We thank CAPES and CNPq, Brazil for scholarships to PLL and JOS, respectively. SLS thanks the Pró-Reitoria de Pesquisa, Pós-Graduação e Extensão (FURB) for Research Grant (Edital Interno). This study is part of the Conservation and Sustainable Management of Below-Ground Biodiversity (CSM-BGBD) project, coordinated by the Tropical Soil Biology and Fertility Institute of CIAT (TSBF-CIAT) with financial support provided by the Global Environmental Facility (GEF) and implementation support by the United Nations Environmental Program (UNEP), and coordinated in Brazil by Dr. F. M. S. Moreira (UFLA, Lavras, MG). The BGBD project is implemented in seven countries (Brazil, Côte d'Ivoire, India, Indonesia, Kenya, Mexico and Uganda) and co-financing is generated from budgets of all partner institutions involved in the project. Carlos R. Grippa is also acknowledged for contribution to soil sampling and set up of traps.

\section{RESUMO}

\section{Ocorrência e diversidade de fungos micorrízicos arbuculares em culturas armadilhas de solos sob diferentes sistema de uso na Amazônia, Brasil}

O objetivo deste trabalho foi avaliar a ocorrência de espécies de fungos micorrízicos arbusculares (FMAs) em amostras de solos da região Amazônica sob diferentes sistemas de uso da terra (Floresta, Capoeira Velha, Capoeira Nova, Sistema Agroflorestal, Culturas e Pastagens) usando dois métodos de culturas armadilhas. Culturas armadilhas estabelecidas com Sorghum sudanense e Vigna unguiculata (na Universidade Regional de Blumenau - FURB) e Brachiaria decumbens e Neonotonia wightii (na Universidade Federal de Lavras - UFLA) foram cultivadas por 150 dias em condições de casa-devegetação e avaliadas para o número de esporos e identificação das espécies. Uma grande variação na riqueza de espécies foi detectada em várias amostras, independente do sistema de uso da terra de onde as amostras foram obtidas. Um total de 24 espécies de FMAs foram recuperadas usando ambas 
metodologias de culturas armadilhas e as culturas estabelecidas na FURB produziram um número maior de espécies. Acaulospora delicata, A. foveata, Entrophospora colombiana e duas espécies não descritas de Glomus foram as espécies mais abundantes e freqüentes recuperadas das culturas armadilhas. O número de espécies diminui em cada gênero na seguinte ordem: Acaulospora, Glomus, Entrophospora, Gigaspora, Archaeospora, Scutellospora e Paraglomus. Número de esporos foi maior na Capoeira jovem e Pastagens. Nosso estudo demonstrou que os FMAs possuem uma ampla dispersão em todos os sistemas de uso na Amazônia e que eles esporulam mais abundantemente em culturas armadilhas estabelecidas de solos sob interferência antrópica do que em solos de Floresta nativa.

Palavras-chave: Floresta Amazônica, fungos do solo, diversidade de espécies, pastagens, sistemas agroflorestais, culturas em potes.

\section{REFERENCES}

1. Aristizábal, C.; Rivera, E.L.; Janos, D.P. (2004). Arbuscular mycorrhizal fungi colonize decomposing leaves of Myrica parvifolia, M. pubescens and Paepalanthus sp. Mycorrhiza 14, 221-228.

2. Bever, J.D.; Morton, J.B.; Antonovics, J.; Schultz, P. (1996). Hostdependent sporulation and species diversity of arbuscular mycorrhizal fungi in a mown grassland. J. Ecology 84, 71-82.

3. Brundrett, M.C.; Abott, L.K. (1991). Roots of Jarrah forest plants. I. Mycorrhizal associations of shrubs and herbaceous plants. Aust. J. Bot. 39, 445-457.

4. Carrenho, R.; Trufem, S.F.B.; Bononi, V.L.R. (2002). Effects of using different host plants on the detected biodiversity of arbuscular mycorrhizal fungi from an agroecosystem. Rev. Bras. Bot. 25, 95101.

5. Fidalgo, E.C.C.; Coelho, M.R.; Araújo, F.O.; Moreira, F.M.S.; Santos, H.G.; Brefin, M.L.M.S.; Huising, J. (2005). Levantamento do uso e cobertura da terra de seis áreas amostrais relacionadas ao projeto "Conservation and Sustainable Management of Below-ground Biodiversity: Phase I", município de Benjamin Constant (AM). Rio de Janeiro: Embrapa Solos. (Boletim de Pesquisa).

6. Gazey, C.; Abbott, L.K.; Robson, A.D. (1992). The rate of development of mycorrhizas affects the onset of sporulation and production of external hyphae by two species of Acaulospora. Myc. Res. 92, 643-650.

7. Gerdemann, J.W.; Nicolson, T.H. (1963). Spores of mycorrhizal Endogone species extracted from soil by wet sieving and decanting. Transactions of the British Mycological Society 46, 235-244.

8. Hammer, O.; Harper, D.A.T.; Ryan, P.A. (2001). Past: Paleontological Statistics Software Package for Education and Data Analysis. Palaeontologica Electronica, vol. 4, issue 1, art. 4:9pp, $178 \mathrm{~kb}$.

9. Janos, D.P. (1996). Mycorrhizas, succession and rehabilitation of deforested lands in the humid tropics. In.: Frankland, J.C., Gadd, G.M. (eds.). Fungi and Environmental Change. Cambridge University Press, Cambridge, UK, p. 1-18.

10. Johnson, N.C.; Wedin, D.A. (1992). Soil carbon, nutrients, and mycorrhizae during conversion of dry tropical forest to grassland. Ecol. Appl. 7, 171-182.

11. Klauberg Filho, O.; Siqueira, J.O.; Moreira, F.M.S. (2002). Vesicular arbuscular mycorrhizae fungi in soils polluted with heavy metals. Rev. Bras. Cienc. Solo 26, 125-134.
12. Kowalchuk, G.A.; Souza, F.A.; van Veen, J.A. (2002). Community analysis of arbuscular mycorrhizal fungi associated with Ammophila arenaria in Dutch coastal sand dunes. Mol. Ecol. 11, 571-581.

13. Liu, R.; Wang, F. (2003). Selection of appropriate host plants used in trap cultures of arbuscular mycorrhizal fungi. Mycorrhiza 13, 123-127.

14. Lovelock, C.E.; Ewel, J.J. (2005). Links between tree species, symbiotic fungal diversity and ecosystem functioning in simplified tropical ecosystems. New Phytologist 167, 219-228.

15. Mangan, A.S.; Eom, A-H.; Adler, G.H.; Yavitt, J.B.; Herre, E.A. (2004). Diversity of arbuscular mycorrhizal fungi across a fragmented forest in Panama: insular spore communities differ from mainland communities. Oecologia 141, 687-700.

16. Melloni, R.; Siqueira, J.O.; Moreira, F.M.S. (2003). Arbuscular mycorrhizal fungi in soils of bauxite mining area under rehabilitation. PAB 38, 267-276.

17. Miller, D.D.; Domoto, P.A.; Walker, C. (1985). Mycorrhizal fungi at eighteen apple rootstocks plantings in the United States. New Phytologist 100, 379-391.

18. Moreira, F.M.S.; Siqueira, J.O.; Brussaard, L. (2006). Soil Biodiversity in Amazonian and Other Brazilian Ecosystems. CABI Publishing, London, UK.

19. Morton, J.B. (1993). Problems and solution for the integration of glomalean taxonomy, systematic biology, and the study of endomycorrhizal phenomena. Mycorrhiza 2, 97-109.

20. Morton, J.B.; Bentivenga, S.P.; Wheeler, W.W. (1993). Germ plasm in the International Collection of Arbuscular and Vesicular-arbuscular Mycorrhizal Fungi (INVAM) and procedures for culture development, documentation and storage. Mycotaxon 48, 491-528.

21. Morton, J.B.; Bentivenga, S.P.; Bever, J.D. (1995). Discovery, measurement, and interpretation of diversity in arbuscular endomycorrhizal fungi (Glomales, Zygomycetes). Can. J. Bot. 73, S25-S32.

22. Newsham, K.K.; Fitter, A.H.; Watkinson, A.R. (1995). Arbuscular mycorrhiza protect an annual grass from root pathogenic fungi in the field. J. Ecol. 83, 991-1000.

23. Oehl, F.; Sieverding, E.; Ineichen, K.; Mader, P.; Boller, T.; Wiemken, A. (2003). Impact of landuse intensity on the species diversity of arbuscular mycorrhizal fungi in agroecosystem of Central Europe. Appl. Environ. Microbiol. 69, 2816-2824.

24. Picone, C. (2000). Diversity and abundance of arbuscular-mycorrhizal fungus spores in tropical forest and pasture. Biotropica 32, 734750 .

25. Ricklefs, R.E. (1989). Speciation and diversity: the integration of local and regional processes. In: Otte, D., Endler, J.A. (eds.). Speciation and its consequences. Sinauer Assoc. Inc., Sunderland, p. 599-621.

26. Rillig, M.C.; Mummey, D.L. (2006). Mycorrhizas and soil structure. New Phytologist 171, 41-53.

27. Schüâler, A.; Schwarzott, D.; Walker, C. (2001). A new fungal phylum, the Glomeromycota: phylogeny and evolution. Mycol. Res. 105, 1413-1421.

28. Silva, G.A. (2005). Infectividade e eficiência de comunidades de fungos micorrízicos arbusculares isoladas de solos sob diferentes sistemas de uso na Região Amazônica. [Infectivity and efficiency of communities of arbuscular mycorrhizal fungi isolated from soils with different use systems at the Amazon Region]. Tese de Mestrado, UFLA. Pp. 62.

29. Siqueira, J.O.; Sylvia, D.M.; Gibson, J.; Hubbell, D.H. (1985). Spores, germination, and germ tubes of vesicular-arbuscular mycorrhizal fungi. Can. J. Microbiol. 31, 965-972.

30. Siqueira, J.O.; Klauberg-Filho, O. (2000). Micorrizas arbusculares: a pesquisa brasileira em perspectiva. In: Novais, R.F., Alvarez, V.H., Schaefer, C.E.G.R. (eds.). Tópicos em Ciência do Solo. UFV, Viçosa, Brasil, p. 235-264. 
31. Siqueira, J.O.; Saggin-Júnior, O.J. (2001). Dependency of arbuscular mycorrhizal fungi and responsiveness of some Brazilian native woody species. Mycorrhiza 11, 245-255.

32. Smith, S.E.; Read, D.J. (1997). Mycorrhizal Symbiosis. Academic Press, London, $605 \mathrm{pp}$

33. Souza, R.G.; Maia, L.C.; Sales, M.F.; Trufem, S.F.B. (2003). Diversity and infectivity potential of arbuscular mycorrhizal fungi in an area of "caatinga" in the Xingó Region, State of Alagoas, Brazil. Rev. Bras. Bot. 26, 49-60.

34. Souza, F.A.; Declerck, S. (2003). Mycelium development and architecture, and spore production of Scutellospora reticulata in monoxenic culture with Ri T-DNA transformed carrot roots. Mycologia 95:1004-1012.

35. Stahl, P.D.; Christensen, M. (1991). Population variation in the mycorrhizal fungus Glomus mosseae - breadth of environmental tolerance. Mycol. Res. 95, 300-307.

36. Stürmer, S.L. (1998). Characterization of diversity of fungi forming arbuscular endomycorrhizae in selected plant communities. Ph.D. Dissertation, West Virginia University, Morgantown, USA.
37. Stürmer, S.L. (2004). Effect of different fungal isolates from the same mycorrhizal community on plant growth and phosphorus uptake in soybean and red clover. Rev. Bras. Cienc. Solo 28, 611-622.

38. Stürmer, S.L.; Siqueira, J.O. (2006). Diversity of arbuscular mycorrhizal fungi in Brazilian ecosystems. In: Moreira, F.M.S. Siqueira, J.O., Brussaard, L. (eds.). Soil Biodiversity in Amazonian and Other Brazilian Ecosystems. CABI, London, UK, p. 206-236.

39. Stutz, J.C.; Morton, J.B. (1996). Successive pot culture reaveal high species richness of arbuscular endomycorrhizal fungi in arid ecosystems. Can. J. Bot. 74, 1883-1889.

40. Van der Heijden, M.G.A.; Klironomos, J.N.; Ursic, M.; Moutoglis, P.; Streitwolf-Engel, R.; Boller, T.; Wiemken, A.; Sanders, I.R. (1998). Mycorrhizal fungal diversity determines plant biodiversity, ecosystem variability and productivity. Nature 396, 69-72.

41. Zangaro, W.; Bononi, V.L.R.; Trufem, S.F.B. (2000). Mycorrhizal dependency, inoculum potential and habitat preference of native woody species in South Brazil. J. Trop. Ecol. 16, 603-621. 